\title{
Ecomorphological relationships of fish assemblages in a trans-Andean drainage, Upper Magdalena River Basin, Colombia
}

\author{
Cristhian C. Conde-Saldaña ${ }^{1}$, Juan G. Albornoz-Garzón ${ }^{1}$, Edwin O. López-Delgado ${ }^{1,2}$ \\ and Francisco A. Villa-Navarro ${ }^{1,3}$
}

Ecomorphological patterns of the fish community were evaluated in the trans-Andean Alvarado River drainage, Colombia. A total of 29 species using 25 ecomorphological indices were analyzed to test how well the ecomorphological patterns are related to the fish assemblage. Although a significant correlation was found (Mantel test) between morphological attributes and trophic guilds, habitat use and distribution across the altitudinal gradient, only the last two were significantly independent of the phylogenetic relationships (partial Mantel test). Regarding the ecomorphological space, two main trends were defined. First, benthic periphytivores and invertivores were characterized by having dorsal or dorsolateral eyes, labial appendages, depressed bodies and well-developed pectoral, ventral and caudal fins, which provide them the ability to stabilize over the substrate and make rapid movements. Second, nektonic detritivore-invertivores and insectivores were found to have laterally compressed bodies, lateral eyes and larger eyes and anal fins. These species use vision during predation, are good continuous swimmers and possess higher maneuverability and stability. These results show that the fish assemblages in the Alvarado River drainage are structured ecomorphologically mainly by habitat and the altitudinal gradient. Therefore, this is evidence of the importance of habitat structure to maintain the functionality of the ecosystem.

Keywords: Alvarado River drainage, Community ecology, Habitat use, Morphological diversity, Neotropical region.

Se evaluaron los patrones ecomorfológicos de la comunidad íctica en la cuenca transandina del Río Alvarado, Colombia. Se analizaron 29 especies empleando 25 índices ecomorfológicos con el fin de evaluar los patrones ecomorfológicos con el ensamblaje de peces. A pesar de que se encontró una correlación significativa (Prueba de Mantel) de los atributos morfológicos con los gremios tróficos, preferencia de hábitat y la distribución de las especies a lo largo del gradiente altitudinal, solamente las dos últimas fueron independientes de la filogenia (Prueba parcial de Mantel). Con relación al espacio ecomorfológico dos patrones fueron identificados. Primero, las especies bentónicas perifitívoras e invertívoras, caracterizadas por ojos dorsales o dorsolaterales, cuerpos deprimidos y aletas desarrolladas, proporcionando la capacidad de estabilizarse sobre el sustrato y realizar movimientos rápidos. Segundo, especies nectónicas detritívoras-invertivoras e insectívoras con cuerpos comprimidos, ojos laterales y mayor área relativa de ojos y aleta anal; estos usan la visión durante la actividad predatoria, con mayor capacidad de maniobrabilidad y estabilización. Estos resultados muestran que el ensamblaje de peces en la cuenca está estructurado principalmente por el uso de hábitat y el gradiente altitudinal, esto podría ser evidencia de la importancia de la estructura del hábitat para garantizar la funcionalidad del ecosistema.

Palabras clave: Cuenca del río Alvarado, Diversidad morfológica, Ecología de comunidades, Región Neotropical , Uso de hábitat.

\section{Introduction}

In adaptive terms, ecomorphology is defined as the analysis of the relationships between the morphological characteristics of a group of organisms and how they relate to the environment (Bock, 1990, 1994). This suggests that morphological differences between species would result from the different selection pressures to which species were subjected (Casatti, Castro, 2006). Therefore, it is possible that morphologically similar species may show signs of resource sharing (Fernández et al., 2012). Within a community, habitat use and some trophic aspects might be related to the species' phenotype (Gatz, 1979b; Gibran, 2010). This is the main hypothesis of ecomorphology, which allows the investigation of species interactions, making it possible to identify the biological role of species using

${ }^{1}$ Grupo de Investigación en Zoología, Facultad de Ciencias, Universidad del Tolima, Barrio Santa Helena parte alta, Ibagué, Tolima, Colombia. (CCCS) ccconde27@gmail.com (corresponding author), (JGAG)jgalbornoz@ut.edu.co, (FAVN) favilla@ut.edu.co

${ }^{2}$ Winemiller Aquatic Lab, Department of Wildlife and Fisheries Sciences, and Biodiversity Research and Teaching Collections, Texas A\&M University, 2258 TAMU, College Station, TX, USA. eolopezd@tamu.edu

${ }^{3}$ Socio-Ecological Systems Laboratory, Department of Ecology, Universidad Autónoma de Madrid, C/Darwin 2, 28049 Madrid, Spain. 
their anatomical characteristics (Gatz, 1979a). In this sense, ecomorphology not only provides an approximation to identify the environment in which species live and how they exploit the resources (Wootton, 1922), but also allows us to detect the niche they occupy and the assemblage structure (Wainwright, Richard, 1995; Hugueny, Poully, 1999). Thus, ecomorphological analysis would be an excellent tool to predict ecological patterns in a set of organisms just using their morphological traits.

Ecomorphological patterns in assemblages could identify species groups that exploit the same ecological resource independently of their phylogenetic relationships (Oliveira et al., 2010; Soares et al., 2013). However, most of the ecomorphological studies in Neotropical fish communities have focused on cis-Andean ecosystems (Casatti, Castro, 2006; Ferreira, 2007; Oliveira et al., 2010; Soares et al., 2013; Neves et al., 2015; Pessanha et al., 2015; RoaFuentes et al., 2015; Novakowski et al., 2016; Prado et al., 2016), which have shown significant relationships between morphological attributes that respond to ecological affinities such as trophic ecology or habitat use. According to Neves et al. (2015), if the theoretical framework of ecomorphological studies is expanded to different geographical areas with high levels of endemism and relatively low richness, it would help to elucidate the different patterns of assemblage structure and interspecific interactions within habitats. Therefore, this study extends the theoretical framework of the ecomorphological hypothesis to the trans-Andean region in Colombia. This region has been characterized by high habitat heterogeneity generated by altitudinal gradients, where the ichthyofauna is defined by high levels of endemism, strong anthropic pressures and low taxonomic resolution (Anderson, Maldonado-Ocampo, 2011; Jiménez-Segura et al., 2016).

Thus, in the current study, we tested how well the ecomorphological patterns are related to the fish assemblage in a trans-Andean basin. Herein we assess two principal aspects: (i) the correlation of morphological attributes of species with habitat type, trophic guilds and/or distribution across the altitudinal gradient without the influence of taxonomic relationships; (ii) to describe and identify possible ecomorphological patterns that reflect ecological aspects such as habitat use, locomotion and trophic ecology of the species.

\section{Material and Methods}

Study area. This study was developed in the Alvarado River (Upper Magdalena River Basin), which has a length of $55 \mathrm{~km}$ and a drainage area of 29,988 ha. This drainage is located on the eastern flank of the Central Cordillera of Tolima Department, Colombia. Nine sampling stations were established from 351 to $1057 \mathrm{~m}$ elevation, both in the main channel (four stations) and in the main tributary streams (five stations) (Fig. 1, Tab. 1).

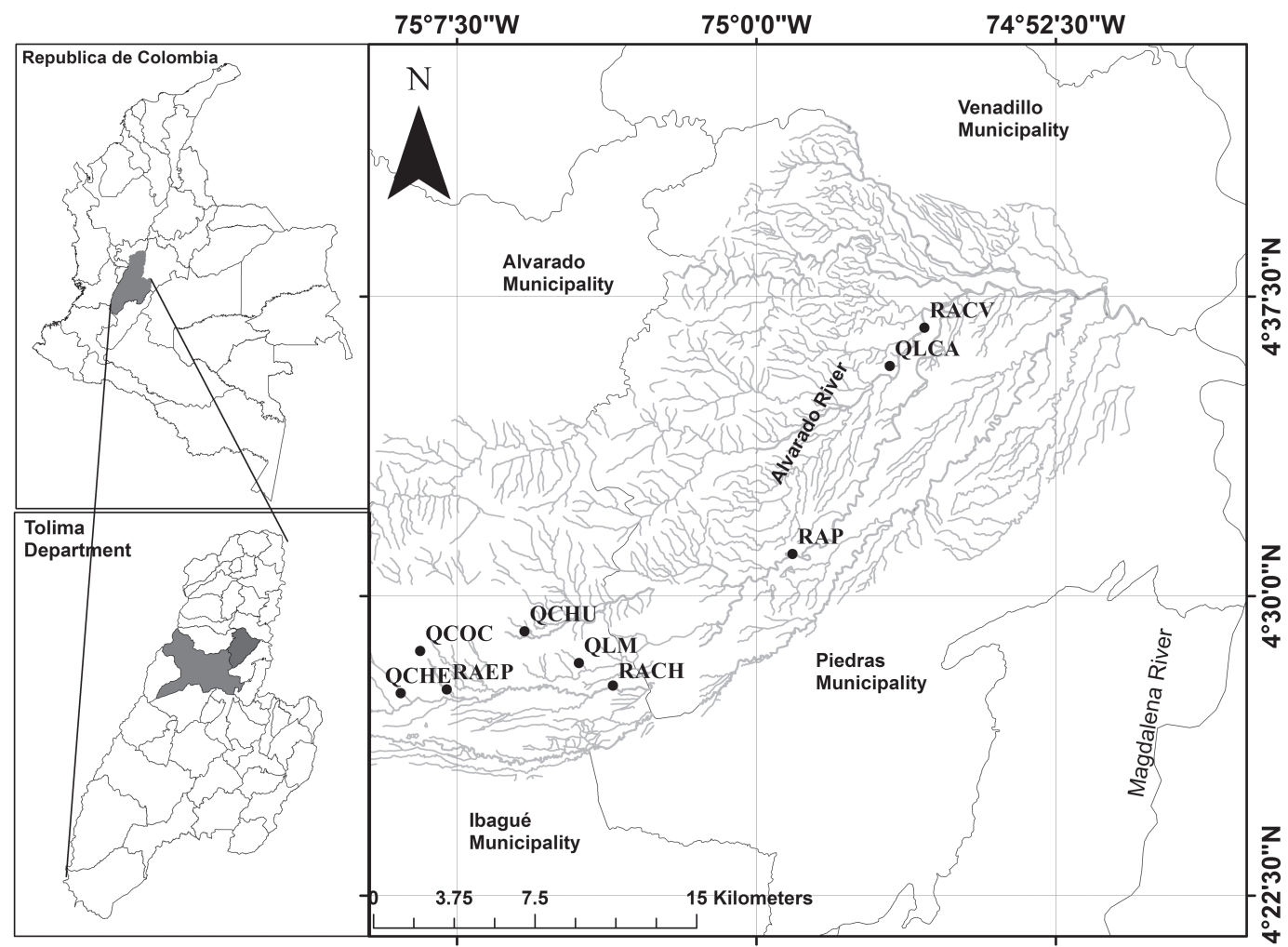

Fig. 1. Study area with the sampling stations in the trans-Andean Alvarado River drainage, Upper Magdalena River Basin, Colombia: QCOC, Quebrada Cocare; QCHE, Quebrada Chembe; QCHU, Quebrada Chumba; RAEP, Alvarado River (El País); QLM, Quebrada La Manjarres; RACH, Alvarado River (Chucuni); RAP, Alvarado River (El Puente); QLCA, Quebrada La Caima; RACV, Alvarado River (Caldas Viejo). 
Tab. 1. Physical and spatial characteristics in the sampling sites in the trans-Andean Alvarado River drainage, Upper Magdalena River Basin, Colombia.

\begin{tabular}{|c|c|c|c|c|c|c|c|}
\hline \multirow{2}{*}{ Sampling station } & \multirow{2}{*}{ Code } & \multirow{2}{*}{ Elevation (m) } & \multirow{2}{*}{ Mean width (m) } & \multirow{2}{*}{ Mean depth (m) } & \multirow{2}{*}{$\begin{array}{c}\text { Mean flow } \\
\left(\mathrm{m}^{3} / \mathrm{s}\right)\end{array}$} & \multicolumn{2}{|c|}{ Geographical coordinates } \\
\hline & & & & & & $\mathrm{N}$ & $\mathrm{W}$ \\
\hline Quebrada Cocare & QCOC & 1057 & $4.7 \pm 1.14$ & $0.24 \pm 0.06$ & $0.61 \pm 0.45$ & $04^{\circ} 28^{\prime} 37.4^{\prime \prime}$ & $75^{\circ} 08^{\prime} 25.4^{\prime \prime}$ \\
\hline Quebrada Chembe & QCHE & 988 & $3.8 \pm 0.89$ & $0.11 \pm 0.04$ & $0.09 \pm 0.08$ & $04^{\circ} 27^{\prime} 34.2^{\prime \prime}$ & $75^{\circ} 08^{\prime} 54.7^{\prime \prime}$ \\
\hline Quebrada Chumba & QCHU & 973 & $5.2 \pm 1.54$ & $0.16 \pm 0.03$ & $0.26 \pm 0.20$ & $04^{\circ} 29^{\prime} 06.2^{\prime \prime}$ & $75^{\circ} 05^{\prime} 48.6^{\prime \prime}$ \\
\hline Río Alvarado -El País & RAEP & 909 & $6.6 \pm 1.59$ & $0.35 \pm 0.10$ & $0.98 \pm 0.54$ & $04^{\circ} 27^{\prime} 37.9^{\prime \prime}$ & $75^{\circ} 07^{\prime} 45.2^{\prime \prime}$ \\
\hline Quebrada La Manjarres & QLM & 758 & $3.4 \pm 0.89$ & $0.10 \pm 0.08$ & $0.08 \pm 0.06$ & $04^{\circ} 28^{\prime} 19.3^{\prime \prime}$ & $75^{\circ} 04^{\prime} 26.9^{\prime \prime}$ \\
\hline Río Alvarado-Chucuni & $\mathrm{RACH}$ & 697 & $8.2 \pm 1.39$ & $0.33 \pm 0.11$ & $1.66 \pm 1.24$ & $04^{\circ} 27^{\prime} 56.7^{\prime \prime}$ & $75^{\circ} 03^{\prime} 46.7^{\prime \prime}$ \\
\hline Río Alvarado-Puente & RAP & 521 & $8.7 \pm 2.14$ & $0.64 \pm 0.51$ & $1.65 \pm 1.41$ & $04^{\circ} 31^{\prime} 11.3^{\prime \prime}$ & $74^{\circ} 59^{\prime} 14.0^{\prime \prime}$ \\
\hline Quebrada La caima & QLCA & 374 & $5.9 \pm 2.39$ & $0.17 \pm 0.05$ & $0.33 \pm 0.25$ & $04^{\circ} 35^{\prime} 45.8^{\prime \prime}$ & $74^{\circ} 56^{\prime} 39.6^{\prime \prime}$ \\
\hline Río Alvarado-Caldas Viejo & RACV & 351 & $10.3 \pm 2.49$ & $0.17 \pm 0.06$ & $0.80 \pm 0.76$ & $04^{\circ} 36^{\prime} 41.2^{\prime \prime}$ & $74^{\circ} 55^{\prime} 46.2^{\prime \prime}$ \\
\hline
\end{tabular}

Sampling. Four sampling campaigns were carried out throughout the annual hydrological cycle: M1 (September 2012, rainy season), M2 (December 2012, dry season), M3 (April 2013, rainy season) and M4 (July 2013, dry season). The seasons were established using the mean values of the precipitation of the last 20 years for the Alvarado River drainage (IDEAM, 2014). Fish collection permit was provided by Corporación Autónoma Regional del Tolima (CORTOLIMA-0491).

Fishes were collected using a backpack electrofisher (SAMUS model $725 \mathrm{M}$ ). Electrofishing was performed in a single pass from downstream to upstream with a variable width (depending on channel width), in a section of $100 \mathrm{~m}$ and a sampling effort of one hour. Two types of habitat, riffles, and pools, were evaluated. These differ according to depth, width, velocity, and flow. Pools were characterized by slow flow and deeper waters areas (Tab. 2). Stream depth was measured by calculating the mean of the depth measurements taken every $1-\mathrm{m}$ intervals along a cross-stream transect (the number of intervals depended on the stream width). Velocity was obtained with a flowmeter (General Oceanics models 2030R and 2030R6) and the flow was calculated using the velocity, depth, and width following the General Oceanics operator's manual.

The fishes collected were anesthetized and euthanized with clove oil (300 mg/L), subsequently, specimens were fixed in $10 \%$ formalin and after $48 \mathrm{~h}$ they were transferred to $70 \%$ ethanol for final preservation.

Tab. 2. Physical characterization of the habitat types evaluated in the trans-Andean Alvarado River drainage, Upper Magdalena River Basin, Colombia.

\begin{tabular}{ccc}
\hline \multirow{2}{*}{ Characteristic } & \multicolumn{2}{c}{ Habitats } \\
\cline { 2 - 3 } & Riffles & Pools \\
\hline Mean velocity $(\mathrm{m} / \mathrm{s})$ & 0.59 & 0.24 \\
Mean depth $(\mathrm{m})$ & 0.20 & 0.30 \\
Mean width $(\mathrm{m})$ & 6.25 & 6.35 \\
Mean flow $\left(\mathrm{m}^{3} / \mathrm{s}\right)$ & 0.87 & 0.57 \\
\hline
\end{tabular}

The specimens were identified in the laboratory, using specialized literature such as Eigenmann $(1922,1912)$, Miles (1971), Dahl (1971), Harold, Vari (1994), Buitrago (1995), Maldonado-Ocampo et al. (2005), and Santana, MaldonadoOcampo (2005). Additionally, species were classified into five trophic guilds (periphytivores, insectivores, invertivores, piscivores and detritivores/invertivores) based on published information about diet and feeding behavior of the ichthyofauna in the Upper Magdalena River Basin (Zúñiga-Upegui et al., 2005; Maldonado-Ocampo et al., 2005; Rojas et al., 2005; Lozano-Zárate et al., 2008; LópezDelgado, 2013). Finally, specimens were deposited in the ichthyological collection of the Universidad del Tolima, Tolima, Colombia (CZUT-IC). The catalog numbers and trophic guild classification are shown in the Tab. 3 .

Linear morphometric measurements, areas and ecomorphological indices. Twenty-three linear morphometric measurements were taken and six areas (eyes and fins) calculated on 29 of the 36 fish species recorded from the study area (Fig. 2, Tab. 3). Only species with more than three individuals were measured, in order to eliminate rare species that could be non-interactive components of the main community (Winemiller, 1991). These measurements were done following the descriptions of Keast, Webb (1966), Gatz (1979b), Winemiller (1991), and Oliveira et al. (2010) (Fig. 2).

Linear morphometric measurements were taken using digital calipers $(0.01 \mathrm{~mm}$ precision), while areas of eyes and fins were obtained from photographs, which were later calculated using Photoshop CS5 software. Photographs were taken with fins extended. Morphological variables were taken, whenever possible, on the left side of specimens. Adult individuals of similar sizes were analyzed to avoid changes in body shape due to ontogenetic development (Sagnes et al., 1997; Mérigoux, Ponton, 1998). Based on the linear morphometric measurements and areas measured, 25 ecomorphological indices related to habitat use, locomotion and trophic ecology were calculated (S1 - Available only as online supplementary file accessed with the online version of the article at http://www.scielo.br/ni). 
Tab. 3. Trans-Andean fish species of the Alvarado River drainage, Upper Magdalena River Basin, Colombia, with their catalog numbers in the ichthyological collection of the Universidad del Tolima, Colombia (CZUT-IC). Habitat association according to the species indicator value (IndVal), trophic guilds and altitudinal group.

\begin{tabular}{|c|c|c|c|c|c|c|c|}
\hline \multirow[t]{2}{*}{ Species } & \multirow[t]{2}{*}{ Abreviation } & \multirow{2}{*}{$\begin{array}{l}\text { Measured } \\
\text { specimens }\end{array}$} & \multirow{2}{*}{$\begin{array}{c}\text { Catalog } \\
\text { number } \\
\text { CZUT-IC }\end{array}$} & \multicolumn{2}{|c|}{$\begin{array}{l}\text { Habitat association } \\
\text { according IndVal }\end{array}$} & \multirow[t]{2}{*}{ Trophic guilds } & \multirow{2}{*}{$\begin{array}{l}\text { Altitudinal } \\
\text { group }\end{array}$} \\
\hline & & & & Riffles & Pools & & \\
\hline \multicolumn{8}{|l|}{ Characiformes } \\
\hline \multicolumn{8}{|l|}{ Parodontidae } \\
\hline $\begin{array}{l}\text { Parodon magdalenensis Londoño-Burbano, } \\
\text { Román-Valencia \& Taphorn, } 2011\end{array}$ & Paromagd & 20 & 10112 & $\mathrm{X}$ & & Periphytivore & $351-587$ \\
\hline \multicolumn{8}{|l|}{ Erythrinidae } \\
\hline Hoplias malabaricus (Bloch, 1794) & Hoplmala & 20 & 10105 & & $\mathrm{X}$ & Piscivore & $351-587$ \\
\hline \multicolumn{8}{|l|}{ Characidae } \\
\hline Argopleura magdalenensis (Eigenmann, 1913) & Argomagd & 20 & 10077 & & $\mathrm{X}$ & Insectivore & $351-587$ \\
\hline Astyanax fasciatus (Cuvier, 1819) & Astyfasc & 20 & 10369 & $\mathrm{X}$ & & Insectivore & $351-587$ \\
\hline Creagrutus affinis Steindachner, 1880 & Creaaffi & 20 & 10139 & & $\mathrm{X}$ & Insectivore & $351-587$ \\
\hline Creagrutus magdalenae Eigenmann, 1913 & Creamagd & 20 & 10079 & $\mathrm{X}$ & & Insectivore & $351-587$ \\
\hline Creagrutus cf. paralacus Harold \& Vari, 1994 & Creapara & 20 & 10246 & $\mathrm{X}$ & & Insectivore & $824-1059$ \\
\hline Gephyrocharax melanocheir Eigenmann, 1912 & Gephmela & 20 & 10099 & & $\mathrm{X}$ & Insectivore & $351-587$ \\
\hline Microgenys minuta Eigenmann, 1913 & Micrminu & 20 & 10061 & $\mathrm{X}$ & & Insectivore & $351-587$ \\
\hline \multicolumn{8}{|l|}{ Siluriformes } \\
\hline \multicolumn{8}{|l|}{ Pimelodidae } \\
\hline Pimelodus yuma Villa-Navarro \& Acero, 2017 & Pimeyuma & 6 & 10352 & $\mathrm{X}$ & & Omnivore & $351-587$ \\
\hline \multicolumn{8}{|l|}{ Heptateridae } \\
\hline Rhamdia guatemalensis (Günther, 1864) & Rhamguat & 11 & 10207 & $\mathrm{X}$ & & Omnivore & $351-587$ \\
\hline Pimelodella cf. chagresi (Steindachner, 1876) & Pimechag & 20 & 10089 & & $\mathrm{X}$ & Invertivore & $351-587$ \\
\hline Heptapteridae new gen. & Heptnuev & 17 & 10088 & $\mathrm{X}$ & & Invertivore & $351-587$ \\
\hline \multicolumn{8}{|l|}{ Trichomycteridae } \\
\hline Trichomycterus banneaui (Eigenmann, 1912) & Tricbann & 20 & 10070 & $\mathrm{X}$ & & Invertivore & $351-587$ \\
\hline Trichomycterus retropinnis Regan, 1903 & Tricretr & 9 & 10281 & & $\mathrm{X}$ & Invertivore & $824-1059$ \\
\hline Trichomycterus sp. & Tricsp & 20 & 10254 & $\mathrm{X}$ & & Invertivore & $824-1059$ \\
\hline \multicolumn{8}{|l|}{ Loricariidae } \\
\hline Chaetostoma milesi Fowler, 1941 & Chaemile & 20 & 10122 & $\mathrm{X}$ & & Periphytivore & $351-587$ \\
\hline Chaetostoma cf. fischeri Steindachner, 1879 & Chaefisc & 20 & 10064 & $\mathrm{X}$ & & Periphytivore & $351-587$ \\
\hline Lasiancistrus caucanus Eigenmann, 1912 & Lasicauc & 20 & 10065 & $\mathrm{X}$ & & Periphytivore & $351-587$ \\
\hline Sturisomatichthys leightoni (Regan, 1912) & Sturleig & 20 & 10082 & $\mathrm{X}$ & & Periphytivore & $351-587$ \\
\hline \multicolumn{8}{|l|}{ Astroblepidae } \\
\hline Astroblepus grixalvii Humboldt, 1805 & Astrgrix & 20 & 10289 & $\mathrm{X}$ & & Invertivore & $824-1059$ \\
\hline Astroblepus homodon (Regan, 1904) & Astrhomo & 20 & 10260 & $\mathrm{X}$ & & Invertivore & $824-1059$ \\
\hline Astroblepus unifasciatus (Eigenmann, 1912) & Astrunif & 15 & 10291 & $\mathrm{X}$ & & Invertivore & $824-1059$ \\
\hline \multicolumn{8}{|l|}{ Gymnotiformes } \\
\hline \multicolumn{8}{|l|}{ Sternopygidae } \\
\hline Sternopygus aequilabiatus (Humboldt, 1805) & Steraequ & 6 & 10163 & & $\mathrm{X}$ & Omnivore & $351-587$ \\
\hline \multicolumn{8}{|l|}{ Cyprinodontiformes } \\
\hline \multicolumn{8}{|l|}{ Cynolebiidae } \\
\hline Cynodonichthys magdalenae (Eigenmann \& Henn, 1916) & Cynomagd & 20 & 10208 & & $\mathrm{X}$ & Invertívoro & $588-823$ \\
\hline Poeciliidae & & & & & & & \\
\hline Poecilia caucana (Steindachner, 1880) & Poeccauc & 20 & 10067 & & $\mathrm{X}$ & Invertivore & $351-587$ \\
\hline Poecilia reticulata Peters, 1859 & Poecreti & 20 & 10209 & & $\mathrm{X}$ & Invertivore & $588-823$ \\
\hline Cichliformes & & & & & & & \\
\hline Cichlidae & & & & & & & \\
\hline Andinoacara latifrons (Steindachner, 1878) & Andilati & 14 & 10110 & & $\mathrm{X}$ & Detritivore-Invertivore & $351-587$ \\
\hline Geophagus steindachneri Eigenmann \& Hildebrand, 1922 & Geopstein & 20 & 10091 & & $\mathrm{X}$ & Detritivore-Invertivore & $351-587$ \\
\hline
\end{tabular}



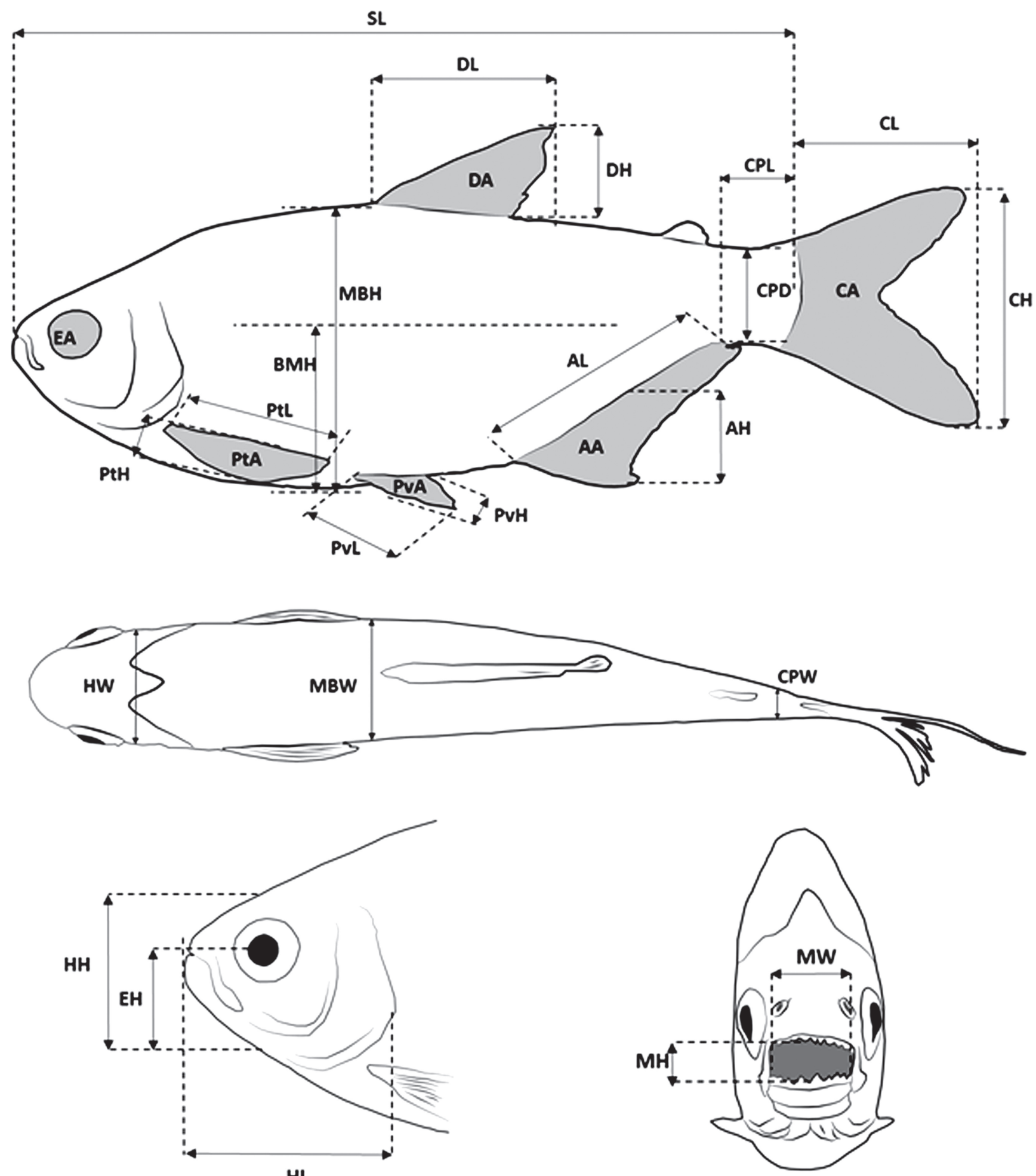

Fig. 2. Representation of the linear morphometric measurements and the calculated areas: standard length (SL), maximum body height $(\mathrm{MBH})$, body midline height $(\mathrm{BMH})$, caudal-peduncle length (CPL), caudal-peduncle depth (CPD), dorsal-fin length (DL), dorsal-fin height (DH), pectoral-fin length (PtL), pectoral-fin height (PtH), pelvic-fin length $(\mathrm{PvL})$, pelvic-fin height $(\mathrm{PvH})$, anal-fin length $(\mathrm{AL})$, anal-fin height $(\mathrm{AH})$, caudal-fin length (CL), caudal-fin height $(\mathrm{CH})$, head width (HW), maximum body width (MBW), caudal peduncle width (CPW), head length (HL), head height (HH), eye height (EH), mouth height (MH), mouth width (MW), eye area (EA), pectoral-fin area (PtA), pelvic-fin area (PvA), dorsal-fin area (DA), caudal-fin area (CA), and anal-fin area (AA). Schematic representation based on Astyanax fasciatus, CZUT-IC 10369. 
Data analysis. Ecomorphological structure. To test the null hypothesis that the morphological patterns (morphological distance) of the trans-Andean fish assemblages of the Alvarado River drainage are independent of the phylogenetic (taxonomic), spatial (habitat use), trophic (trophic guilds) and altitudinal (altitudinal gradient) structures, a Mantel analysis was performed (Anderson, Walsh, 2013). This test is a correlation between two dissimilarity matrices and the statistical significance is obtained by $n$ randomizations of the data of one of the matrices. The null hypothesis is that the matrices are not linearly or monotonically related (Smouse et al., 1986; Legendre, Legendre, 2012).

Morphological distances. A Euclidean distance matrix was made for each pair of species based on their ecomorphological indices. This matrix was generated using the decostand function of the R library Vegan ( $R$ Development Core Team, 2017) (S2 - Available only as online supplementary file accessed with the online version of the article at http://www.scielo.br/ni).

Taxonomic distance. This matrix was constructed based on the methodology proposed by Douglas, Matthews (1992). A value of one was attributed to the pairs of congeneric species, a value of 1.5 to those in different genera, but the same subfamily; a value of two in different subfamilies, but the same family; a value of three to the different families but the same order; a value of four to the different order but the same superorder; and to species from different superorders were designated a value of five (S3 - Available only as online supplementary file accessed with the online version of the article at http:// www.scielo.br/ni).

Habitat use. The abundance data was used to establish habitat association; this type of data is a good predictor of the relationships between fish and their habitats (Rosenfeld, 2003). Because abundance did not differ seasonally based on a nonparametric exploratory analysis (Kruskal-Wallis test performed in R software), the data was pooled to establish the species association in each habitat type (riffles and pools) (S4 - Available only as online supplementary file accessed with the online version of the article at http://www.scielo.br/ni). The indicator value method (IndVal) proposed by Dufrêne, Legendre (1997) was used to establish species habitat association. Each species was assigned to a type of habitat according to the results of the maximum indicator value for each type of habitat (maxcls option). This analysis was performed using the Indval function of the $\mathrm{R}$ library labdsv ( $\mathrm{R}$ Development Core Team, 2017). To generate the distance matrix of habitat use, a value of one was given to the pair of species that belong to the same habitat type and two for species that did not satisfy this condition. This matrix was created following the approach proposed by Soares et al.
(2013) (S5 - Available only as online supplementary file accessed with the online version of the article at http:// www.scielo.br/ni).

Trophic guilds. The trophic distance matrix was constructed using the trophic guild classification. A value of one was attributed to the pair of species belonging to the same guild and a value of two for species belonging to different guilds, as proposed by Soares et al. (2013) (S6 - Available only as online supplementary file accessed with the online version of the article at http://www.scielo.br/ni).

Altitudinal gradient matrix. To generate the altitudinal matrix, three groups with different altitudinal gradients (351-587 m; 588-823 m; 824-1059 m) were generated by taking the square root of the number of observations or as in this case the number of sampling locations (Montgomery, Runger, 1994; Maio et al., 2000). Once the groups were defined, the abundance data in each sampling location was used to perform the IndVal analysis. Species classification in each altitudinal group was done using the maxcls option from the Indval function of the R library labdsv (R Development Core Team, 2017). Each pair of species belonging to the same gradient was given a value of one, and a value of two was given to species that did not satisfy this condition, following the methodology proposed by Soares et al. (2013) (S7 - Available only as online supplementary file accessed with the online version of the article at http://www.scielo.br/ni).

Correlation between morphology and habitat use and trophic structures could be due to phylogenetic artifacts that could lead us to spurious correlations (Douglas, Matthews, 1992). Because of this, a partial Mantel test was used. It assesses the partial correlation between two matrices (morphological distance vs. trophic guilds, and morphological distance $v s$. habitat use) controlling for the effect of a third matrix (taxonomic distances). Mantel and partial Mantel test were carried out using the mantel and partial.mantel functions from the R library Vegan; statistical significance was estimated using 20,000 permutations (R Development Core Team, 2017).

Ecomorphological patterns. Principal Components Analysis (PCA) was used to identify patterns of fish assemblages distribution in the multivariate ecomorphological space. The PCA was applied on the correlation matrix composed by the mean values of the 25 ecomorphological indices previously transformed with $\log (\mathrm{x}+1)$. The components retained for interpretation were chosen according to the Broken-stick model (Jackson, 1993) in which a pattern of expected eigenvalues is estimated and only those components that exceed these values will be considered significant. These analyses were performed using the rda function from the R library vegan and the PCA significance function from the $\mathrm{R}$ package BiodiversityR (R Development Core Team, 2017). 


\section{Results}

Ecomorphological structure. The Mantel test revealed a significant correlation between the matrix of morphological distance and taxonomic distance $(\mathrm{r}=0.21 ; \mathrm{p}=0.01)$, spatial structure $(\mathrm{r}=0.18 ; \mathrm{p}=0.004)$, trophic structure $(\mathrm{r}=0.12$; $\mathrm{p}=0,02)$ and altitudinal structure $(\mathrm{r}=0.22 ; \mathrm{p}=0.016)$. However, after controlling for the taxonomic relationships, only spatial and altitudinal structure showed a significant effect $(r=0.13 ; p=0.013$ and $r=0.24 ; p=0.025)$, suggesting that fish morphology was a good predictor of habitat use and altitudinal distribution of the trans-Andean fish assemblages of the Alvarado River drainage.

Ecomorphological patterns. The PCA revealed the formation of five significant components according to the Broken-stick model which explained $82.03 \%$ of the total variation in the ecomorphospace (Fig. 3). However, only the first two components were used for interpretation accounting for $48.91 \%$ of the total variation. Although, the third factor accounted for $17.91 \%$ of the variation, it did not provide additional information about the ecomorphological patterns, nor did the fourth (8.26\%) and fifth (6.93\%) components (Tab. 4). The ecomorphological traits with greater influence in the morphospace were related to habitat use and feeding. These were position of the eye, relative area of the eye, presence of barbels or labial appendages, compression index, mouth position, relative depth, relative area of the pectoral fin, relative head length, relative area of the caudal fin and relative area of the ventral fin.

In the first component (26.6\% of the variation), the species with the lowest negative scores were characterized by small eyes located dorsally or dorsolaterally, presence of chin or labial appendages, ventral or inferior mouth, broader head and depressed body, characteristics that allow them to be categorized as benthic consumers of periphyton or invertebrates. This group was composed mainly by Siluriformes including families such as: Astroblepidae, Trichomycteridae, Heptapteridae, Pimelodidae and Loricariidae (Fig. 3). Species with more positive scores in this factor were associated with traits related to use of vision during their predatory activity, laterally compressed bodies and greater relative area of the anal fin. These traits are related to a high potential for maneuverability and stabilization of movement and they are associated with nektonic habits and tendency to feed on insects and invertebrates. These features are typical of cynolebiids, poeciliids, characids, and cichlids (Fig. 3).

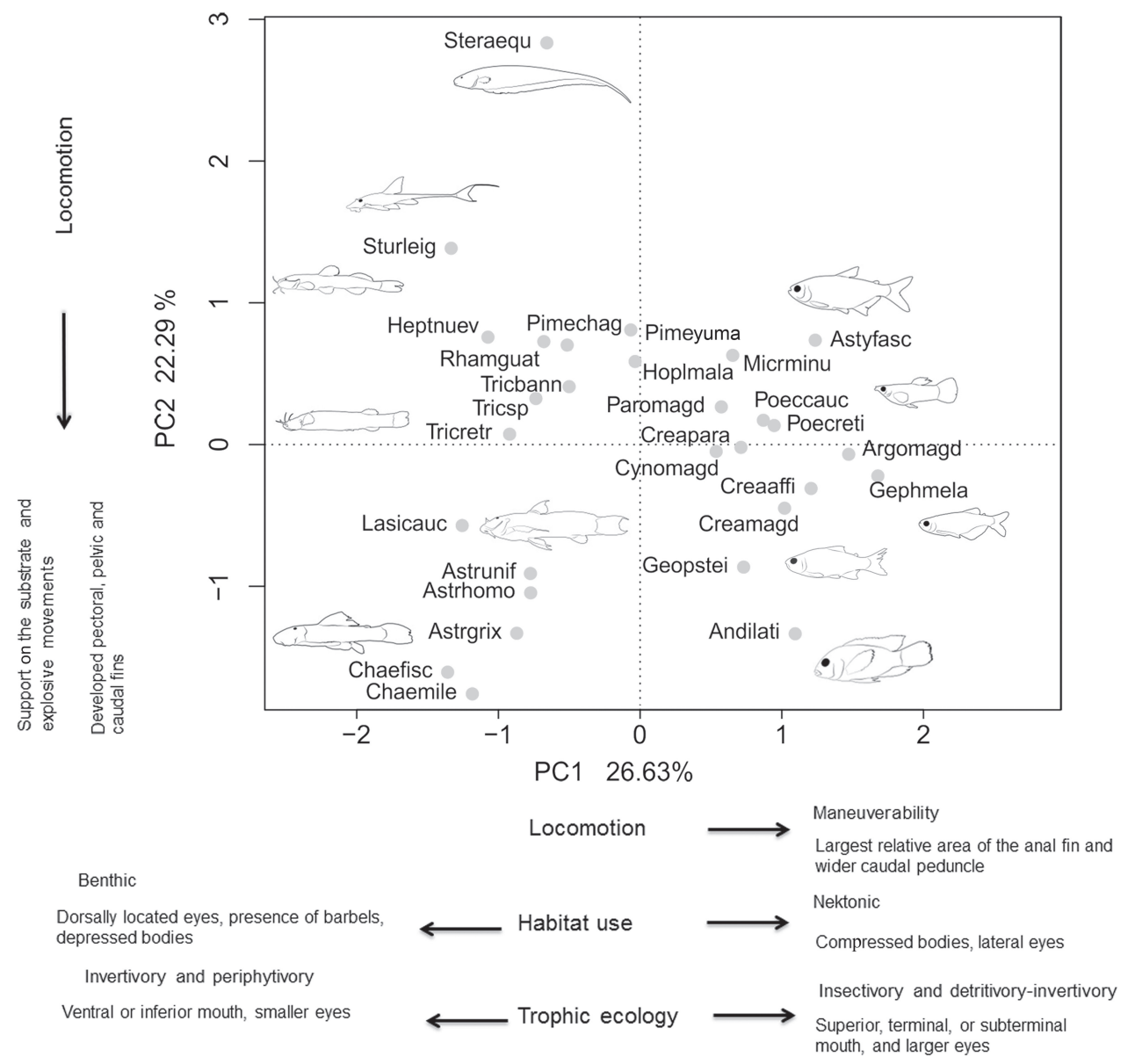

Fig. 3. Projection of the two principal components of 29 fish species in the trans-Andean basin of the Alvarado River, Upper Magdalena, Colombia. List of species abbreviations in Tab. 3. 
In relation to the second component $(22.3 \%$ of the variation), the variables with greater importance were related to locomotion and habitat use. Species with higher positive scores were characterized by a greater development of the pectoral and ventral fins, characteristic of species with benthic habits. Likewise, they had a greater development of the dorsal and caudal fins, characteristic of active swimmers or benthic species that perform rapid explosive movements. Although the third component did not reveal additional information about the ecomorphological patterns, it showed a high value of the aspect ratio of the anal fin that could be responsible for the separation of the knifefish Sternopygus aequilabiatus in the ecomorphological space produced by the first two components (Fig. 3).

Tab.4. Eigenvalues and contribution of the ecomorphological indices in the first three axes from the principal components (PCA) applied to the correlation matrix formed by 25 attributes of the 29 species analyzed from the trans-Andean Alvarado River drainage, Upper Magdalena River Basin, Colombia. The indices with higher correlation values for each principal component (PC) were shown in bold and selected for interpretation.

\begin{tabular}{lccc}
\hline Ecomorphological indices & PC 1 & PC 2 & PC 3 \\
\hline Compression index (CI) & $\mathbf{0 . 8 2 5}$ & -0.219 & -0.183 \\
Depression index (DI) & $\mathbf{- 0 . 4 8 1}$ & 0.265 & 0.194 \\
Relative depth (RD) & $\mathbf{0 . 8 2 1}$ & 0.410 & 0.235 \\
Eye position (EP) & $\mathbf{- 0 . 9 0 4}$ & 0.295 & 0.099 \\
Relative area of pelvic fin (RAPv) & -0.199 & $\mathbf{0 . 7 3 0}$ & 0.495 \\
Aspect ratio of pelvic fin (ARPv) & 0.094 & $\mathbf{0 . 6 4 6}$ & -0.602 \\
Relative area of pectoral fin (RAPt) & 0.141 & $\mathbf{0 . 8 1 7}$ & 0.492 \\
Aspect ratio of pectoral fin (ARPt) & 0.029 & 0.574 & -0.608 \\
Relative lenght of caudal peduncle (RLPd) & -0.326 & -0.090 & 0.218 \\
Caudal peduncle compression index (CIPd) & 0.212 & 0.575 & -0.591 \\
Relative height of caudal peduncle (RHPd) & -0.208 & 0.540 & -0.467 \\
Relative width of caudal peduncle (RWPd) & $\mathbf{0 . 4 9 6}$ & -0.098 & -0.063 \\
Relative area of dorsal fin (RAD) & -0.030 & $\mathbf{0 . 5 9 8}$ & 0.727 \\
Relative area of caudal fin (RAC) & 0.421 & $\mathbf{0 . 7 5 0}$ & 0.290 \\
Aspect ratio of caudal fin (ARC) & 0.387 & 0.469 & -0.399 \\
Relative area of anal fin (RAA) & $\mathbf{0 . 7 8 1}$ & 0.010 & 0.186 \\
Aspect ratio of anal fin (ARA) & 0.186 & 0.444 & $\mathbf{- 0 . 6 9 6}$ \\
Relative lenght of head (RLHd) & 0.221 & $\mathbf{0 . 7 7 0}$ & 0.376 \\
Relative height of head (RHHd) & -0.478 & 0.560 & 0.498 \\
Relative width of head (RWHd) & $\mathbf{- 0 . 6 2 1}$ & 0.270 & -0.406 \\
Relative height of mouth (RHM) & -0.304 & -0.290 & 0.559 \\
Relative width of mouth (RWM) & -0.267 & 0.295 & -0.485 \\
Relative area of eye (RAE) & $\mathbf{0 . 8 6 1}$ & 0.207 & 0.301 \\
Mouth position (MP) & $\mathbf{- 0 . 6 7 2}$ & 0.242 & 0.037 \\
Presence of barbel (Pb) & $\mathbf{- 0 . 8 7 0}$ & 0.147 & -0.140 \\
Eigenvalue & 6.66 & 5.57 & 4.47 \\
Explained variance (\%) & 26.63 & 22.29 & 17.91 \\
Accumulated variance (\%) & 26.63 & 48.92 & 66.83 \\
Broken-stick percentege & 15.26 & 11.26 & 9.26 \\
\hline
\end{tabular}

\section{Discussion}

The ecomorphological hypothesis poses that the morphology of each species could reflect important characteristics of their ecologies and therefore, be a good predictor of the way species exploit resources such as habitat or diet preference (Gatz, 1979b; Watson, Balon, 1984; Wood, Bain, 1995; Oliveira et al., 2010). However, few studies have evaluated the predictive ability of fish morphology in trans-Andean rivers, which are characterized by high habitat heterogeneity generated by altitudinal gradients and high levels of endemism (Anderson, Maldonado-Ocampo, 2011). In this study, habitat use and altitudinal distribution showed a significant correlation with species morphology, after controlling for phylogenetic effects. These results imply that fish assemblage in the trans-Andean Alvarado River drainage is ecomorphologically structured, making possible predictions about habitat use and altitudinal distributions based on morphological features. It means that if two similar morphological species are sampled independent of trophic guilds and taxonomic positions, there is a high probability that these species use the same habitat or altitudinal gradient.

Assessments of the ecomorphological hypothesis in cis-Andean basins (Casatti, Castro, 2006; Soares et al., 2013) have reported clear evidence that ecomorphological attributes mainly related to body shape play a pivotal role determining habitat use and positions in the water column. In this study, morphological attributes such as depth and lateral body compression, and the development of pectoral, pelvic and caudal fins, were significantly related to habitat use. These features have been documented and associated with habitat exploitation, particularly when water velocity is an important ecological factor (Hora, 1930; Wood, Bain, 1995; Sagnes et al., 1997; Cunico, Agostinho, 2006). These traits play an important role in aquatic ecosystems because they influence the distribution and composition of fish assemblages according to their requirements and the resources offered in the different habitats (riffles and pools) generated by water velocity gradients (Nikolski, 1933).

Additionally, there is strong evidence of changes in fish community along altitudinal gradients; several studies have shown that the diversity of Neotropical fishes decreases with elevation (Lomolino, 2001; Jaramillo-Villa et al., 2010; Carvajal-Quintero et al., 2015). This pattern has been correlated with limiting factors such as water temperature, dissolved oxygen, $\mathrm{pH}$, slope and stream width (JaramilloVilla et al., 2010; De La Barra et al., 2016), as well as the decrease in primary productivity and complexity of habitats (Alvarez-Leon, Ortiz-Muñoz, 2004). Few studies, however, have assessed the ability of morphological features to predict altitudinal distribution of fish species. In this study, we present evidence of how fish morphology influences composition and distribution of fish assemblages along the altitudinal gradient. For instance, species found in upper portions of the gradient were characterized by streamlined bodies that reduce water resistance (Langerhans, 2008), 
and oral modifications such as suction cup-like lips for clinging to rock surfaces (Crop et al., 2013). In this sense, the environmental conditions typical of each altitudinal gradient could be related to the process of adaptation and speciation in Neotropical mountain streams (Aguirre et al., 2016; Malato et al., 2017).

Although trophic behavior has been related to morphology (Gatz, 1979b; Hugueny, Pouilly, 1999; Pouilly et al., 2003; Ward-Campbell et al., 2005; Ferreira, 2007; Oliveira et al., 2010), the absence of a significant relationship in this study could be due to the low capacity of some ecomorphological indices used to describe trophic ecology and to the trophic differences between some morphologically similar species. Additionally, the absence of this correlation can occur for reasons such as seasonality in resources, phenotypic plasticity in developmental traits or complex indirect interactions (Binning, Chapman, 2010). The ecomorphological mismatch between morphology and diet has also been found in different studies that used ecomorphological traits based on external characters (Casatti, Castro, 2006; Soares et al., 2013; Novakowski et al., 2016) instead of attributes such as length of intestine, shape of the stomach, number of pyloric caeca, location and shape of teeth, number and length of gill arches, or the length and distance between gill rakers (Winemiller, 1991; Fugi et al., 2001; Pouilly et al., 2003; Sánchez et al., 2003). These traits could reveal more information about the trophic ecology of the species.

In the ecomorphological space of the fish community of the Alvarado River drainage, two main trends were defined. The first one associates periphytivores and invertivores with benthic habits mainly belonging to the order Siluriformes such as loricariids (Chaetostoma milesi and Chaestoma cf. fischeri), astroblepids (Astroblepus grixalvii, A. homodon, and $A$. unifasciatus), trichomycterids (Trichomycterus banneaui, $T$. retropinnis, and $T$. sp.) and heptapterids (Pimelodella cf. chagresi, Rhamdia guatemalensis, and Heptapteridae new genus). This group was characterized by species with dorsally located eyes, presence of chin or labial appendages, depressed bodies and increased development in pectoral, pelvic and caudal fins, which provided the ability to stabilize on the substrate and to perform rapid explosive movements (Lundberg, March, 1976; Gatz, 1979b; Watson, Balon, 1984). Most species included in this group have an affinity for riffles. For example, species of the families Astroblepidae and Loricariidae possess morphological traits typical of fish inhabiting stony substrates with torrential currents, such as a sucker mouth, depressed body and paired fins positioned horizontally (Hora, 1930; Crop et al., 2013). However, in this case, the morphological similarity is not related to their trophic ecology. The diet of loricariids is mainly organic detritus and periphyton, correlated with features such as maxillary teeth arranged to form rake-like structure and long intestines (Delariva, Agostinho, 2001; ZuñigaUpegui et al., 2005, López-Delgado, 2013). Astroblepids on the other hand, have a diet based on aquatic insects (Diptera, Ephemeroptera, and Trichoptera) and present characteristics such as incisive or bicuspid teeth, a short esophagus, and intestines (Miles, 1971; Buitrago, 1995).

The second trend in the ecomorphological space was represented by the orders Characiformes, Cyprinodontiformes, and Cichliformes. This group was associated with a greater relative area of the eyes and anal fin, compressed bodies, lateral eyes and a deeper caudal peduncle in relation to the body, which are defining characteristics of species with nektonic habits. These species were characterized by the use of vision during their predatory activity, being good continuous swimmers and/or possessing a greater capacity of maneuverability and stabilization of movement (Watson, Balon, 1984; Pankhurst, 1989; Breda et al., 2005). Characids were the predominant group showing this trend; these species have laterally compressed bodies, small dorsal fins and relatively elongated pectorals fins, which allow the movement throughout the water column, as well as the use of different types of habitats (Casatti, Castro, 2006; Ferreira, 2007). Cyprinodontiformes and Cichliformes have attributes such as larger fin area and lateral compression that allow them to efficiently exploit habitats with high structural complexity like quiet backwater systems (Breda et al., 2005; Nunes, Hartz, 2006; Oliveira et al., 2010).

Species such as Parodon magdalenensis, Hoplias malabaricus and Pimelodus yuma were located in the center of the ecomorphological space; this has been related to fusiform bodies in other ecomorphological studies of fish communities (Casatti, Castro, 2006; Oliveira et al., 2010). Theoretically, fusiform bodies are advantageous for locomotion at high speed, allowing a greater propulsive force (Breda et al., 2005). However, this body shape can be generalized and does not necessarily reflect habitat selection or exploitation of a particular resource (Oliveira et al., 2010; Bower, Piller, 2015). In that case, the phenotype would probably not reflect habitat use or resource acquisition. These could be related to other biological processes such as behavior (Bower, Piller, 2015). Sternopygus aequilabiatus was the only nektobenthic species found. It has an elongated body, reduced pectoral fins, prolonged anal fin and lack of dorsal and caudal fin (Maldonado-Ocampo et al., 2005). These morphological features allow this knifefish to swim forward, backward or stay stationary (Lannoo, Lannoo, 1993; Ferreira, 2007), which would facilitate its survival in the pools among the roots of riparian vegetation (Ferreira, 2007; López-Delgado, 2013).

Ecomorphology is an important tool for the prediction of niche space (Prado et al., 2016). Therefore, understanding ecomorphological patterns in fish assemblages can play an important role in conservation, because species losses not only represent the disappearance of biological entities, but also the alteration of ecological groups and the loss of functional roles that species play in the ecosystem (Neves et al., 2015). Habitat loss by damming, mining, 
deforestation, and pollution is one of the main threats to the Neotropical fish fauna (Barletta et al., 2010; Anderson, Maldonado-Ocampo, 2011; Pelicice et al., 2017). Also, the maintenance of the natural hydrological variability and good practices of land use are essential to ensure habitat heterogeneity, which contributes to the ecosystem conservation and the integrity of rivers (Schlosser, 1991; Poff et al., 1997; Abujanra et al., 2009; Fernandes et al., 2009). Studies have shown (Willis et al., 2005) that a higher degree of structural complexity in habitats promotes higher primary and secondary productivity, resulting in a greater variety of niches, and the provision of space and food supply for the resident biota. Fish distribution in aquatic ecosystems is highly dynamic, and spatial heterogeneity is an important aspect of species life history in natural ecosystems (Schlosser, 1991). Therefore, because fish assemblages in the Alvarado River drainage are mainly structured by habitat type and altitudinal gradients, fish communities could be highly sensitive to changes in the habitat structure along the river. We conclude that these results emphasize the importance of habitat structure to maintain the functionality of the ecosystem and assembly processes that support fish community structure and dynamics.

\section{Acknowledgments}

We thank to the Comité Central de Investigaciones y Desarrollo Científico de la Universidad del Tolima (UT) for financial support (Project number 90213). We also thank all the members of the Grupo de Investigación en Zoología (GIZ) who helped us with the fieldwork and to Dr. Donald Taphorn for his comments that helped us improve this manuscript.

\section{References}

Abujanra F, Agostinho AA, Hahn, NS. Effects of the flood regime on the body condition of fish of different trophic guilds in the Upper Paraná River floodplain. Braz J Biol. 2009; 69(2):469-79.

Aguirre WE, Navarrete R, Malato G, Calle P, Loh MK, Vital, WF, Valadez G, Vu V, Shervette R, Granda JC. Body shape variation and population genetic structure of Rhoadsia altipinna (Characidae: Rhoadsiinae) in Southwestern Ecuador. Copeia. 2016; 104(2):554-69.

Alvarez-Leon R, Ortiz-Muñoz V. Distribución altitudinal de las familias de peces en tributarios de los ríos Magdalena y Upía. Only Dhalia. 2004; 7(1): 87-94.

Anderson EP, Maldonado-Ocampo JA. A regional perspective on the diversity and conservation of tropical Andean fishes. Conserv Biol. 2011; 25(1):30-39.

Anderson MJ, Walsh DC. PERMANOVA, ANOSIM, and the Mantel test in the face of heterogeneous dispersions: what null hypothesis are you testing? Ecological Monographs. 2013. 83(4):557-74.
Barletta M, Jaureguizar AJ, Baigun C, Fontoura NF, Agostinho AA, Almeida-Val VMF, Val AL, Torres RA, Jiménez-Segura LF, Giarrizzo T, Fabré NN, Batista VS, Lasso C, Taphorn DC, Costa MF, Chaves PT, Vieira JP, Corrêa MFM. Fish and aquatic habitat conservation in South America: a continental overview with emphasis on neotropical systems. J Fish Biol. 2010; 76(9):2118-76.

Binning, SA, Chapman, LJ. Is intraspecific variation in diet and morphology related to environmental gradients? Exploring Liem's paradox in a cichlid fish. Integr Zool. 2010; 5(3):241-55.

Bock WJ. From biologische anatomie to ecomorphology. Neth J of Zool. 1990; 40(1):254-77.

Bock WJ. Concepts and methods in ecomorphology. J Biosci. 1994; 19(4):403-13.

Bower LM, Piller KR. Shaping up: a geometric morphometric approach to assemblage ecomorphology. J Fish Biol. 2015; 87(3):691-714.

Breda L, Oliveira EF, Goulart E. Ecomorfologia de locomoção de peixes com enfoque para espécies neotropicais. Acta Sci Biol Sci. 2005; 27(4):371-81.

Buitrago UA. Sistemática de las especies colombianas del género Astroblepus Humboldt 1805 (Pisces: Siluroidei: Astroblepidae) [ M.Sc. Dissertation]. Bogotá D.C.: Universidad Nacional de Colombia; 1995.

Carvajal-Quintero JD, Escobar F, Alvarado F, Villa-Navarro FA, Jaramillo-Villa Ú, Maldonado-Ocampo JA. Variation in freshwater fish assemblages along a regional elevation gradient in the northern Andes, Colombia. Ecol Evol. 2015; 5(13):2608-20.

Casatti L, Castro RMC. Testing the ecomorphological hypothesis in a headwater riffles fish assemblage of the rio São Francisco, southeastern Brazil. Neotrop Ichthyol. 2006; 4(2):203-14.

Crop W, Pauwels E, Hoorebeke LV, Geerinckx T. Functional morphology of the Andean climbing catfishes (Astroblepidae, Siluriformes): alternative ways of respiration, adhesion, and locomotion using the mouth. J Morphol. 2013; 274(10):1164-79.

Cunico AM, Agostinho AA. Morphological patterns of fishes and their relationships with reservoirs hydrodynamics. Braz Arch Biol Tech. 2006; 49(1):125-34.

Dahl G. Los peces del norte de Colombia. Ministerio de Agricultura, Instituto de Desarrollo de los Recursos Naturales Renovables (INDERENA). Bogotá D.C: Talleres Litografía Arco; 1971.

De La Barra E, Zubieta J, Aguilera G, Maldonado M, Pouilly M, Oberdorff T. ¿Qué factores determinan la distribución altitudinal de los peces de ríos tropicales andinos? Rev Biol Trop. 2016; 64(1):157-76.

Delariva RL, Agostinho AA. Relationship between morphology and diets of six neotropical loricariids. J Fish Biol. 2001; 58(3):832-47.

Douglas ME, Matthews WJ. Does morphology predict ecology? Hypothesis testing within a freshwater stream fish assemblage. Oikos. 1992; 65(2):213-24.

Dufrêne M, Legendre P. Species assemblages and indicator species: the need for a flexible asymmetrical approach. Ecol Monogr, 1997; 67(3):345-66. 
Eigenmann CJ. Some results from an ichthyological reconnaissance of Colombia, South America. Bloomington (IN): Indiana University; 1912. (Contributions from the zoological laboratory of Indiana University, Indiana University studies; vol 1, No. 18).

Eigenmann CJ. The fishes of the Northwestern South America, part I. The fresh-water fishes of Northwestern South America, including Colombia, Panamá, and Pacific slopes of Ecuador and Perú, together with an appendix upon the fishes of the río Meta in Colombia. Mem Carnegie Mus. 1922; 9(1):1-346.

Fernandes R, Agostinho AA, Ferreira EA, Pavanelli CS, Suzuki HI, Lima DP, Gomes LC. Effects of the hydrological regime on the ichthyofauna of riverine environments of the Upper Paraná River floodplain. Braz J Biol. 2009; 69(2):669-80.

Fernández EM, Ferriz RA, Bentos CA, López GR. Dieta y ecomorfología de la ictiofauna del arroyo Manantiales, provincia de Buenos Aires, Argentina. Rev Mus Argent Cienc Nat. 2012; 14(1):1-13.

Ferreira KM. Biology and ecomorphology of stream fishes from the río Mogi-Guacu basin, Southeastern Brazil. Neotrop Ichthyol. 2007; 5(3):311-26.

Fugi R, Agostinho AA, Hahn NS. Trophic morphology of five benthic-feeding fish species of a tropical floodplain. Rev Bras Biol. 2001; 61(1):27-33.

Gatz J. Community organization in fishes as indicated by morphological features. Ecology. 1979a; 60(4):711-18.

Gatz J. Ecological morphology of freshwater stream fishes. Tulane Stud Zool Bot. 1979b; 21(2):91-124.

Gibran FZ. Habitat partitioning, habits and convergence among coastal nektonic fish species from the São Sebastião Channel, southeastern Brazil. Neotrop Ichthyol. 2010; 8(2):299-310.

Harold AS, Vari RP. Systematics of the trans-Andean species of Creagrutus (Ostariophysi: Characiformes: Characidae). Smith Contrib Zoo. 1994; 551:1-31.

Hora SL. Ecology, bionomics and evolution of the torrential fauna, with special reference to the organs of attachment. Phil Trans R Soc Lond B. 1930; 218:171-282.

Hugueny B, Poully M. Morphological correlates of diet in an assemblage of West African freshwater fishes. J Fish Biol. 1999; 54(6):1310-25.

Instituto de Hidrología, Meteorología y Estudios Ambientales (IDEAM). (Date of access - 18 March 2014). 2014. Available from: https://www.datos.gov.co/Ambiente-y-DesarrolloSostenible/Promedios-Precipitaci-n-y-Temperatura-mediaPromed/nsxu-h2dh

Jackson DA. Stopping rules in principal components analysis: a comparison of heuristical and statistical approaches. Ecology. 1993; 74(8):2204-14.

Jaramillo-Villa U, Maldonado-Ocampo JA, Escobar F. Altitudinal variation in fish assemblage diversity in streams of the central Andes of Colombia. Journal of Fish Biology, 2010; 76(10):2401-17.

Jiménez-Segura LF, Ortega H, Chuchtaya J, Jiménez-Prado P, Carvajal-Vallejos FM, Rivadeneira JF, Mojica JI, Mesa LM, Sánchez-Duarte P, Maldonado-Ocampo JA, Correa V, Chocano L, Velásquez MA, Hidalgo M, Usma S, Lasso CA,
Anderson PE, Villa-Navarro FA, Tognelli MF. Capítulo 3. Estado de conservación y distribución de los peces de agua dulce de los Andes Tropicales. In: Tognelli MF, Lasso CA, Bota-Sierra CA, Jiménez-Segura L. F, Cox NA, editores. Estado de conservación y distribución de la biodiversidad de agua dulce en los Andes Tropicales. Gland, Suiza, Cambridge, UK y Arlington, USA: UICN; 2016. p.23-55.

Keast A, Webb D. Mouth and body form relative to feeding ecology in the fish fauna of a small lake, Lake Opinicon, Ontario. J Fish Res Board Can. 1966; 23(12):1845-74.

Langerhans RB. Predictability of phenotypic differentiation across flow regimes in fishes. Integr Comp Biol. 2008; 48(6):750-68.

Lannoo MJ, Lannoo SJ. Why do electric fishes swim backwards? An hypothesis based on gymnotiform foraging behavior interpreted through sensory constraints. Environ Biol Fish. 1993; 36(2):157-65.

Legendre P, Legendre LF. Numerical ecology. 3rd ed. Amsterdam, Elsevier. 2012.

Lomolino MV. Elevation gradients of species-density: historical and prospective views. Global Ecol Biogeogr. 2001; 10(1):313. doi: 10.1046/j.1466-822x.2001. 00229.x

López-Delgado E. Composición y estructura de la comunidad de peces y sus relaciones con la calidad de la vegetación riparia y algunas variables ambientales en dos ríos de bosque seco tropical (Bs-T), Tolima (Colombia). [M.Sc. Dissertation]. Ibagué, Tolima: Universidad del Tolima; 2013.

Lozano-Zárate YY, Villa-Navarro FA, García-Melo LJ, GarcíaMelo JE, Reinoso-Flórez G. Aspectos bioecológicos de Microgenys minuta (Characidae) en la Cuenca del río Totare, sistema río Magdalena, Colombia. Dahlia. 2008; 10:65-82.

Lundberg JG, March E. Evolution and functional anatomy of the pectoral fin rays in cyprinoid fishes, with emphasis on the suckers (Family Catostomidae). Am Midl Nat. 1976; 96(2):332-49.

Maio C, Schexnayder C, Knutson K, Weber S. Probability distribution functions for construction simulation. J Constr Eng Manag. 2000; 126(4):285-92.

Maldonado-Ocampo JA, Ortega-Lara A, Usma-Oviedo JS, Galvis-Vergara G, Villa-Navarro FA, Vasquez-Gamboa L, Prada-Pedreros S, Ardila C. Peces de los Andes de Colombia. Bogotá D.C: Instituto de Investigación de Recursos Biológicos Alexander von Humboldt; 2005.

Malato G, Shervette VR, Navarrete Amaya R, Valdiviezo Rivera J, Nugra Salazar FN, Calle Delgado P, Karpan KC, Aguirre WE. Parallel body shape divergence in the Neotropical fish genus Rhoadsia (Teleostei: Characidae) along elevational gradients of the western slopes of the Ecuadorian Andes. PLoS One. 2017; 12(6):e0179432.

Mérigoux S, Ponton D. Body shape, diet and ontogenetic diet shifts in young fish of the Sinnamary River, French Guiana, South America. J Fish Biol. 1998; 52(3):556-69.

Miles C. Los peces del río Magdalena. 2nd ed. Ibagué: Universidad del Tolima. Centro Audiovisual. UT ediciones; 1971.

Montgomery DC, Runger GC. Applied statistics and probability for engineers. New York: Wiley; 1994. 
Neves MP, Delariva RL, Wolff LL. Diet and ecomorphological relationships of an endemic, species-poor fish assemblage in a stream in the Iguaçu National Park. Neotrop Ichthyol. 2015; 13(1):245-54.

Nikolski GV. On the influence of rate of flow on the fish fauna of the rivers of Central Asia. J Anim Ecol. 1933; 2(2):266-81.

Novakowski GC, Cassemiro FA, Hahn NS. Diet and ecomorphological relationships of four cichlid species from the Cuiabá River basin. Neotrop Ichthyol. 2016; 14(3): e150151.

Nunes DM, Hartz SM. Feeding dynamics and ecomorphology of Oligosarcus jenynsii (Gunther, 1864) and Oligosarcus robustus (Menezes, 1969) in the lagoa Fortaleza, southern Brazil. Braz J Biol. 2006; 66(1A):121-32.

Oliveira EF, Goulart E, Breda L, Minte-Vera CV, Paiva LRS, Vismar MR. Ecomorphological patterns of the fish assemblage in a tropical floodplain: Effects of trophic, spatial and phylogenetic structures. Neotrop Ichthyol. 2010; 8(3):569-86.

Pankhurst NW. The relationship of ocular morphology to feeding modes and activity periods in shallow marine teleosts from New Zealand. Environ Biol Fish. 1989; 26(3):201-11.

Pelicice FM, Azevedo-Santos VM, Vitule JR, Orsi ML, Lima Junior DP, Magal-es ALB, Pompeu PS, Petrere M, Jr., Agostinho AA. Neotropical freshwater fishes imperilled by unsustainable policies. Fish Fish. 2017; 18(1):1119-33.

Pessanha ALM, Araújo FG, Oliveira REM, Silva AF, Sales NS. Ecomorphology and resource use by dominant species of tropical estuarine juvenile fishes. Neotrop Ichthyol. 2015; 13(2):401-12.

Poff NL, Allan JD, Bain MB, Karr JR, Prestegaard KL, Richter BD, Sparks RE, Stromberg JC. The natural flow regime. BioScience. 1997; 47(11):769-84.

Pouilly M,LinoF, Bretenoux JG, Rosales C. Dietary-morphological relationships in a fish assemblage of the Bolivian Amazonian floodplain. J Fish Biol. 2003; 62(5):1137-58.

Prado AVR, Goulart E, Pagotto JPA. Ecomorphology and use of food resources: inter-and intraspecific relationships of fish fauna associated with macrophyte stands. Neotrop Ichthyol, 2016; 14(4):e150140.

R Development Core Team. 2017. R: a language and environment for statistical computing. $\mathrm{R}$ Foundation for Statistical Computing. R Foundation for Statistical Computing, Vienna, Austria. Available from http://www.Rproject.org/.

Roa-Fuentes CA, Casatti L, Romero RM. Phylogenetic signal and major ecological shifts in the ecomorphological structure of stream fish in two river basins in Brazil. Neotrop Ichthyol. 2015; 13(1):165-78.

Rojas JE, Soca LA, García GI. Contenido del tracto digestivo de 4 especies de peces autóctonos y sus implicaciones como biorreguladores de larvas de mosquitos en Venuezuela. Rev Cubana Med Trop. 2005; 57(3):1-8.
Rosenfeld J. Assessing the habitat requirements of stream fishes: an overview and evaluation of different approaches. T Am Fish Soc. 2003; 132(5): 953-68.

Sagnes P, Gaudin P, Statzner B. Shifts in morphometrics and their relation to hydrodynamic potential and habitat use during grayling ontogenesis. J Fish Biol. 1997; 50(4):846-58.

Sánchez RM, Galvis G, Victoriano PF. Relación entre características del tracto digestivo y los hábitos alimentarios de peces del río Yuaco, sistema del río Meta (Colombia). Gayana. 2003; 67(1):75-86

Santana CD, Maldonado-Ocampo JA. Apteronotus milesi, new species of ghost knifefish (Gymnotiformes: Apteronotidae) from the Cauca River, with a key to apteronotids from the Magdalena-Cauca basin, Colombia. Ichthyol Explor Fres. 2005; 16(3):223-30.

Schlosser IJ. Stream fish ecology: a landscape perspective. BioScience. 1991; 41(10):704-12.

Smouse PE, Long JC, Sokal RR. Multiple regression and correlation extensions of the Mantel Test of matrix correspondence. Syst Zool. 1986; 35(4):627-32.

Soares BE, Ruffeil TOB, Montag LFA. Ecomorphological patterns of the fishes inhabiting the tide pools of the Amazonian coastal zone, Brazil. Neotrop Ichthyol. 2013; 11(4):845-58.

Ward-Campbell BMS, Beamish FWH, Kongchaiya C. Morphological characteristics in relation to diet in five coexisting Thai fish species. J Fish Biol. 2005; 67(5):1266-79.

Watson DJ, Balon EK. Ecomorphological analysis of fish taxocenes in rainforest streams of northern Borneo. J Fish Biol. 1984; 25(3):371-84.

Wainwright PC, Richard AB. Predicting patterns of prey use from morphology of fishes. Environ Biol Fish. 1995; 44(1-3):97-113.

Willis SC, Winemiller KO, Lopez-Fernandez H. Habitat structural complexity and morphological diversity of fish assemblages in a Neotropical floodplain river. Oecologia. 2005; 142(2):284-95.

Winemiller KO. Ecomorphological diversification in lowland freshwater fish assemblages from five biotic regions. Ecol Monogr. 1991; 61(4):343-65.

Wood BM, Bain MB. Morphology and microhabitat use in stream fish. Can J Fish Aquat Sci. 1995; 52(7):1487-98.

Wootton RJ. Fish ecology. New York: Chapman and Hall; 1922.

Zúñiga-Upegui P, Villa-Navarro FA, Reinoso-Flórez G, OrtegaLara A. Relación longitud-peso y frecuencia de tallas para los peces del género Chaetostoma (Siluriformes, Loricariidae), de la cuenca del río Coello, Colombia. Dahlia. 2005; 8:47-52.

Submitted March 18, 2017 Accepted November 16, 2017 by Fernando Pelicice 